\title{
GROWTH-RING DISTINCTNESS AND BOUNDARY ANATOMY VARIABILITY IN TROPICAL TREES
}

\author{
Yegor Tarelkin ${ }^{1,2,{ }^{*}}$, Claire Delvaux ${ }^{2}$, Maaike De Ridder ${ }^{2}$, Thomas El Berkani ${ }^{1}$, \\ Charles De Cannière ${ }^{1}$, and Hans Beeckman ${ }^{2}$ \\ ${ }^{1}$ Landscape Ecology and Plant Production Systems Unit, Université libre de Bruxelles, CP 264/2, \\ 1050 Bruxelles, Belgium \\ ${ }^{2}$ Wood Biology Service, Royal Museum for Central Africa (RMCA), Leuvensesteenweg 13, \\ 3080 Tervuren, Belgium \\ *Corresponding author: yegor.tarelkin@ulb.ac.be
}

\begin{abstract}
The phenomenon of distinct, absent or indistinct growth rings is a highly variable feature used for wood identification and a wide range of tree-ring studies. Causes for its variability are not yet fully understood. There is also a lack of consensus within the scientific community about how distinct and indistinct tree rings should be defined and classified. We use a selection of 103 Central African rainforest trees to analyse the anatomy of growth-ring boundaries of 103 Central African rainforest species and assessed the influence of the climate, tree organ and leaf shedding behaviour on growth-ring distinctness and anatomy. We observed a high variability of tree-ring boundaries anatomy and distinctness within and among individuals and species. Although, for some semi-deciduous species, higher incidence of distinct growth rings appears to be related with a more pronounced seasonal climate, no general trends are observed for the assembly of studied species. Growth rings are variable within individuals depending on the considered organ: trunks tend to show more distinct rings than branches. Growth-ring distinctness is difficult to implement as a trait to measure tree performance when only based on abrupt changes in fibre size and cell wall thickness. From the potential growth-ring markers identified in the IAWA list of hardwood features, those applying to vessel and parenchyma density and distended rays appear to be more useful in tropical trees than abruptly flattened latewood fibres or abrupt changes in vessel diameter.
\end{abstract}

Keywords: Growth rings, Democratic Republic of the Congo, increment core, branch, wood anatomy, phenology.

Note: Supplementary raw data can be accessed in the online edition of this journal via http://booksandjournals.brillonline.com/content/journals/

\section{INTRODUCTION}

The presence or absence of (in)distinct growth rings is a wood anatomical feature familiar to everybody involved in wood research. Distinct growth rings contribute to the decorative value of wood and also drew the attention of the first scientific observers. 
The first observations of growth rings with the unaided eye were done by Theophrastes (McBride 1983) and Da Vinci (Studhalter et al. 1963). Van Leeuwenhoek was the first to study growth rings in temperate trees under a microscope (Schierbeek 1959). He also made microscopic observations of tropical Diospyros wood (Baas 1982; Baas \& Vetter 1989) and noted the absence of distinct growth rings. Presence or absence of distinct growth rings is the start of many dichotomous identification keys for commercial timbers (IAWA Committee 1989), whereas in fossil wood it is also a criterion to characterise the climate of the geological era where the fossils originate from (Francis \& Hill 1996).

Growth-ring formation is supposed to be triggered by a succession of favourable and unfavourable growing conditions (Schweingruber 1996; Whitmore 1998). The cambial response of trees varies mainly with the environment, the species and the age of a tree (e.g., Fonti et al.2010; De Ridder et al.2013; De Micco et al.2016). Besides, a variety of wood anatomical structures defining growth rings are reported. This complexity leads to different 'levels' of growth-ring distinctness (Schweingruber 1996). For example, Fahn (1962) recognised five types of periodicity of cambial activity in trees and shrubs from Israel, essentially based on growth-ring distinctness. The first type shows growth rings, the middle three types "more or less" distinct growth rings and the fifth does not show growth rings at all. Carlquist (2001) described 15 growth-ring types and Worbes (2010) reduced them to four basic types. Next to these classifications, many other studies in temperate and tropical regions use their own classification, mostly directed towards the applicability in dendrochronological studies (Tarhule \& Hughes 2002; Schweingruber et al. 2006; Sonsin et al. 2012; Groenendijk et al. 2014). Thus, the necessity of a clear and at the same time broad definition of growth-ring distinctness is obvious in order to construct databases on ring characteristics for different species and individuals in different environments. Especially under tropical circumstances there is a high level of growth-ring distinctness variability and uncertainty (Wils et al.2009).

The most used and well-known definition proposed by IAWA (IAWA Committee 1989) defines distinct growth-ring boundaries by an abrupt structural change at the boundary, usually including change in fibre wall thickness and/or radial fibre diameter. In addition six other growth ring-markers, often co-occurring with changes in fibre morphology are listed. The abrupt changes should allow for an exact association of each cell to one single growth ring. IAWA Feature 1 is reserved for species showing distinct growth rings with an abrupt structural change at the growth-ring boundaries, while Feature 2 is for indistinct growth rings, with a more or less gradual change in cell characteristics on a radial axis, and absent rings. However, the classification between Features 1 and 2 remains often arbitrary and largely depends on the judgement of the individual wood anatomist, often biased by his/her origins. Cherubini et al. (2013) used one olive branchwood sample and circulated it for growth-ring analysis to different laboratories. The number of counted growth rings varied considerably among the experts showing the subjective character of growth-ring distinctness.

An alternative approach to wood anatomical descriptions consists of chemical composition studies along growth rings with markers like calcium crystals or oxygen or carbon isotopes (Gourlay 1995; Poussart et al. 2004). Growth seasonality is then 
studied by the periodic variation in concentration of isotopes or mineral inclusions stored in wood. Finally, wood specific gravity profiles from pith to bark may also indicate a periodicity in cambial activity (Worbes 1995). High-resolution X-ray tomography scans can detect small zones with anatomical fluctuations that influence wood specific gravity (e.g., flattened fibres) and could thus provide quantitative data for the determination of growth-ring boundaries complementary to classical wood anatomy (Van den Bulcke et al. 2009; Bastin et al. 2015).

Next to wood anatomy and dendrochronology, protocols on trait measurements and trait analyses per se are becoming increasingly important to study complex ecosystems (e.g., Cornelissen et al. 2003; Pérez-Harguindeguy et al. 2013; Beeckman 2016; Bräuning et al. 2016). Violle et al. (2007) define traits as "any morphological, physiological or phenological feature measurable at the individual level, without reference to the environment or any other level of organisation". Lachenbruch and McCulloh (2014) introduce a temporal notion in the definition of traits. For them, traits are "features of the plant unit that influence hydraulic or mechanical function and (...) will maintain the same value over the period in which the performance is evaluated". Growth-ring distinctness is supposed to enable the measurement of a tree's sensitivity to environmental variations. These variations can be seasonal or extreme events (e.g., ENSO). These stressful events may induce the creation of intra-annual density fluctuations (IADFs) or false rings which might have the same anatomical features as growth rings (De Micco et al. 2016). Both the study of growth-ring width and IADFs anatomy may improve understanding of climate-growth relationships and climate reconstruction in tropical regions (Fonti et al. 2010; Venegas-Gonzales et al. 2015).

In this study, we use the IAWA features and definition of growth rings to describe growth-ring boundaries of a set of species from Central Africa with particular attention to the anatomical diversity. Based on these case studies, the following questions are addressed: does growth-ring distinctness and its variability depend on: a) the climate (species at two distant sampling sites with different precipitation regimes), b) tree organ (trunks vs branches), c) deciduous or evergreen phenology? Finally, the use of growth-ring distinctness as a trait is discussed based on the results of this study.

\section{MATERIAL AND METHODS}

\section{Use of existing collections and database}

Wood collection of the RMCA - The XylaREDD collection of tropical Congolese wood specimens stored in the Royal Museum of Central Africa (RMCA) was browsed and 103 species (Annex 1) were selected based on the number of available high-quality microtome sections. Those microscopic samples were observed under the microscope (Olympus BX60) and the anatomy of detected growth rings was described. Some samples did not show any visible ring boundaries, in which case rings were marked absent. Growth rings were tested for the presence or absence of several features such as abrupt changes in fibre or vessel dimensions or parenchyma frequency variation (Table 1). After the analyses of the different growth-ring markers growth rings were defined as present if fibre wall thickness or radial fibre diameter abruptly changed according to 
Table 1. List of anatomical features used to describe growth-ring boundaries.

\begin{tabular}{ll}
\hline Abbreviation & Anatomical feature \\
\hline AC_FW & Abrupt change in fibre wall thickness \\
AC_FD & Abrupt change in radial fibre diameter \\
GC_FD & Gradual change in radial fibre diameter \\
GC_VD & Gradual change in vessel diameter \\
VDV & Vessel density variation \\
MP & Marginal parenchyma present \\
PDV & Parenchyma bands density variation \\
DR & Distended rays \\
\hline
\end{tabular}

the IAWA definition (IAWA Committee 1989). All analysed features are illustrated in Figure 1. The influence of site, tree organ and phenology was addressed with statistical analyses described in the "Data analysis" paragraph.

For 13 out of 103 species, sampled at the Luki Biosphere Reserve in 2015, both trunk and branch samples were available, and these were compared for any differences in growth ring distinctness. Observations were done either on long micro sections according to Gaertner and Nievergelt (2010), on thin sections, or on finely sanded transverse surfaces of increment cores. The species and number of samples per trunk or branch are presented in Table 2 .

\section{Phenology}

Phenological data for each species were extracted from the INERA(Institut National pour l'Etude et la Recherche Agronomiques) observations that took place from 1948 to 1957 in the Biosphere Reserve of Luki. Two categories were created: evergreen and semi-deciduous. Species were classified as semi-deciduous if several individuals were

Table 2: Species for which both branches and trunkwood samples are available. All samples originate from the Luki Biosphere Reserve.

\begin{tabular}{lcc}
\hline Species & Number of branch samples & Number of trunk samples \\
\hline Blighia welwitschii & 5 & 4 \\
Carapa procera & 6 & 3 \\
Celtis mildbraedii & 5 & 4 \\
Chrysophyllum africanum & 5 & 3 \\
Cola griseiflora & 6 & 5 \\
Erythrophleum suaveolens & 5 & 3 \\
Garcinia punctata & 5 & 1 \\
Petersianthus macrocarpus & 5 & 6 \\
Polyalthia suaveolens & 6 & 5 \\
Pycnanthus angolensis & 5 & 4 \\
Staudtia kamerunensis & 5 & 4 \\
Trichilia gilgiana & 6 & 3 \\
Trilepisium madagascariense & 5 & 3 \\
\hline
\end{tabular}



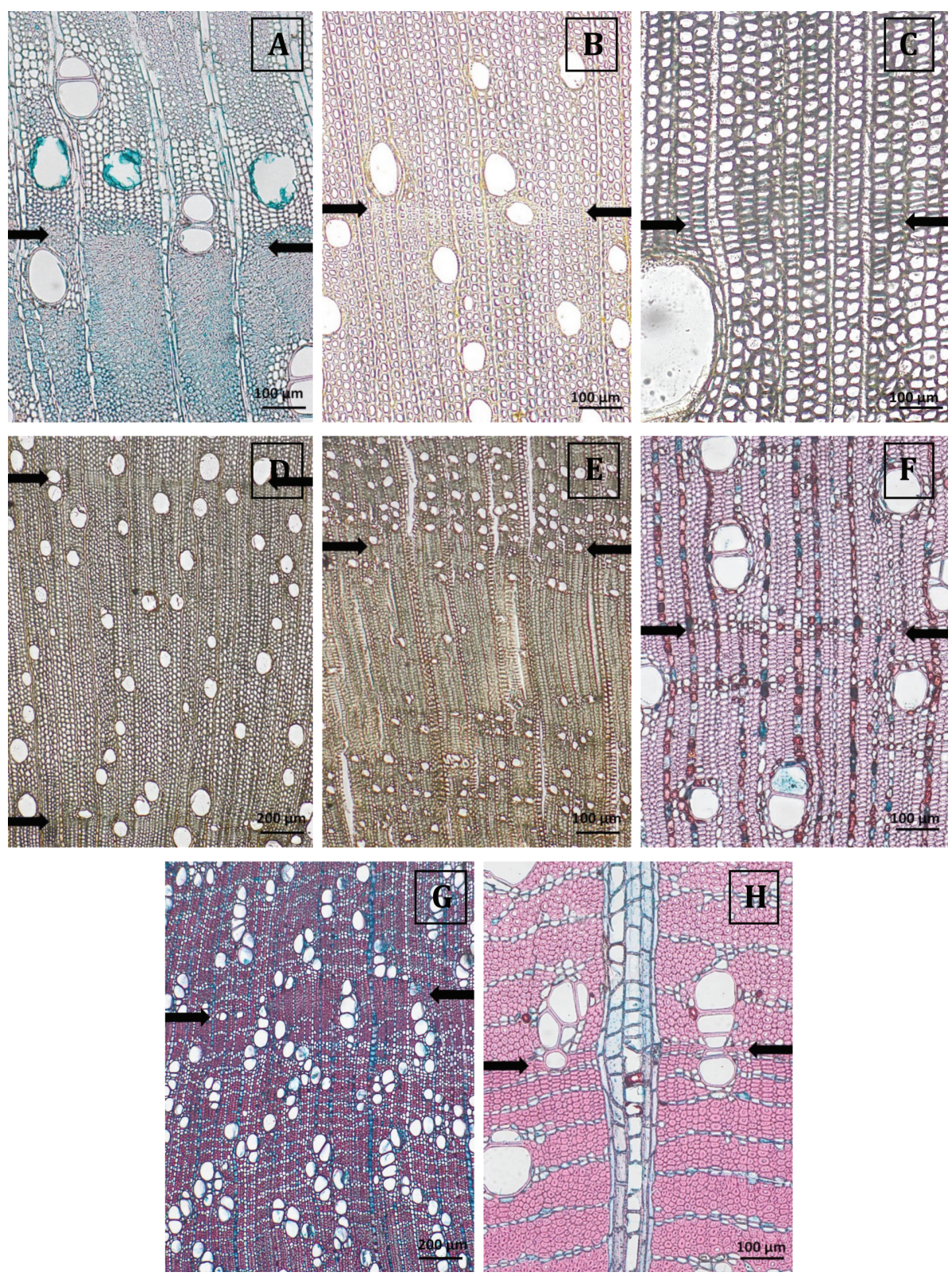

Figure 1. Illustration plates for the studied anatomical features. - A: Abrupt change in fibre wall thickness (Copaifera mildbraedii). - B: Abrupt change in radial fibre diameter (Agelaea pentagyna). - C: Gradual change in radial fibre diameter (Ricinodendron heudelotii). - D: Gradual change in vessel diameter (Agelaea pentagyna). - E: Vessel density variation (Dichapetalum madagascariense). - F: Marginal parenchyma present (Trichilia rubescens). - G: Parenchyma bands density variation (Synsepalum subcordatum). - H: Distended rays (Polyalthia suaveolens). Arrows represent growth ring boundaries. 
observed leafless during the observation period (Couralet et al.2010). Other databases were available (CJB - African Plants Database, Prota4U), however, not all the species were described for their phenological characteristics and some species were described as both "evergreen" and "deciduous". The INERA database had the advantage of being site specific. Also, information about the methodology used to construct the database was available and identical for all the species.

\section{Study sites}

Analyses were conducted on samples collected in the Democratic Republic of the Congo (DRC). Site selection was based on the availability of sufficient numbers of samples from those sites and contrasting rainfall regimes in order to compare growth dynamics between different zones. The sites are located in the Biosphere Reserves of Yangambi $\left(0.46^{\circ} \mathrm{N} 24.28^{\circ} \mathrm{E}\right)$ and Luki $\left(5.39^{\circ} \mathrm{N} 13.4^{\circ} \mathrm{E}\right)$. Annual precipitation is highest in Yangambi (around $1700 \mathrm{~mm}$ ) and decreases to around $1200 \mathrm{~mm}$ in Luki.

The Biosphere Reserve of Yangambi is located on the northern bank of the Congo River, just north of the equator in the Oriental Province. The region has an Af type tropical rainforest climate (following Köppen-Geiger; Peel et al. 2007). Soils on the Yangambi plateau are ferralsols primarily formed from eolian sediments, composed mostly of quartz sand, kaolinite clay and hydrated iron oxides (Gilson 1956; Van

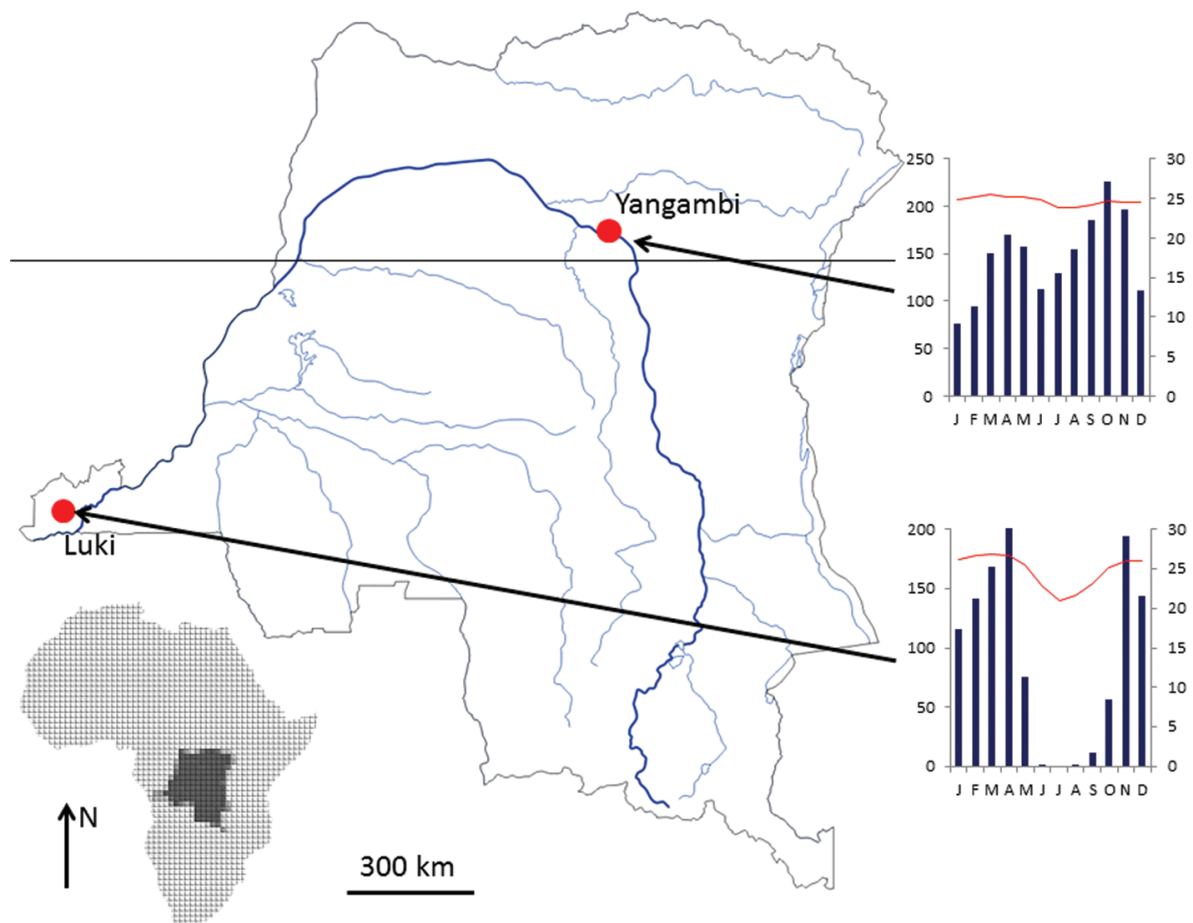

Figure 2. Geographical location of the two study sites with climate diagrams: monthly precipitation left, average day temperature (red line) right. The horizontal line represents the equator. 
Ranst et al. 2010). The Yangambi region receives an annual precipitation of $1762 \mathrm{~mm}$ (1961-2012) with, on average, two to three months with lower monthly precipitation around $100 \mathrm{~mm}$, during December-February (Fig. 2). A smaller season with less precipitation occurs in June to July. Temperatures are fairly constant throughout the year with a minimum of $24.2^{\circ} \mathrm{C}$ in July and a maximum of $25.5^{\circ} \mathrm{C}$ in March. Vegetation in the reserve is characterized by both old-growth and disturbed forests (Gilson 1956). Forest disturbance is mainly caused by slash-and-burn agricultural activities followed by abandonment allowing forest regeneration (Kearsley 2013).

The Biosphere Reserve of Luki is situated in the Lower Congo Province at an altitude of $<300 \mathrm{~m}$ above sea level, in a semi-evergreen rainforest occurring in a mosaic landscape with patches of savanna and successional forest types. The dry season lasts approximately four to five months, from May to September-October. The proximity of the ocean, however, buffers the intensity of the dry period with relative humidity more or less constant throughout the year. Average temperatures are around $26^{\circ} \mathrm{C}$ and annual precipitation varies around $1100 \mathrm{~mm}$ (De Ridder et al. 2013). The soils of the Luki Reserve are classified as orthic ferralsols (FAO 2007). The rainforest is a mixture of deciduous and evergreen tree species in the upper canopy and mostly evergreen species in the understory (Donis 1948; Lebrun \& Gilbert 1954; Couralet et al. 2010). Also, the semi-evergreen mature rainforest encloses other vegetation types which can be relatively widespread (e.g., Marantaceae open forests, woodland savanna types dominated by Xylopia aethiopica and regenerating forest dominated by Terminalia superba, especially abundant in and around the Luki reserve (Donis 1948; Hubau et al . 2015)).

\section{Data analysis}

Each observed growth ring was described by the presence/absence of eight different anatomical features (Table 1) and a score of respectively 1 or 0 assigned per feature. In case of several rings with different anatomical features per individual, an average was calculated per individual per feature. A PCA was then conducted on the sample set to determine how anatomical features interact. A dissimilarity matrix was also constructed with Euclidian distances between PCA's site scores and a clustering (Ward's method) performed (Fig. 4). Five groups were subsequently defined and trends in growth-ring anatomy of the samples within these different groups were analysed. The formation of five clusters was retained because it allowed the best separation of individuals in anatomically homogeneous groups. It also allowed working with a limited number of groups which is easier for the discussion of general trends. The proportion of samples from different sites, organs and phenological character was calculated for each group. All these analyses were performed with $\mathrm{R}$ software with vegan and gclust packages.

\section{RESULTS}

\section{Growth-ring boundaries anatomy variability}

324 individuals sorted in 103 species from the XylaREDD collection were analysed with, on average, 3.2 individuals per species; $28 \%$ (91 individuals) presented distinct 
growth rings. Another $28 \%$ (91 individuals) presented indistinct growth rings while $44 \%$ (142) had no growth rings at all. Growth-ring distinctness was decided on the basis of IAWA's definition of distinct growth rings. Results for XylaREDD samples are presented in Annex 1 (supplementary material).

\section{Climate}

The proportion of individuals originating from Yangambi in our sample set is $60 \%$ (194 individuals) and samples from Luki make up 40\% (130 individuals). These $60-40 \%$ proportions are also observed in groups exclusively composed of individuals with distinct, indistinct and absent rings. In Yangambi, 26\% (50) of individuals have distinct growth rings, $30 \%$ (58) indistinct and $44 \%$ (86) show no rings at all, while in Luki those proportions are very similar.

\section{Tree organs}

The sample set was composed of 51\% (162) of individuals sampled from branches with a diameter of a few centimetres, $42 \%$ (131) from the trunk and 7\% (23) of samples of ambiguous origin, i.e., either from thick branches or of thin main stems (8 individuals had no metadata about the sampled organ). In branch samples, $27 \%$ (43) of individuals had distinct growth rings, $25 \%$ (41) showed indistinct rings and $48 \%$ (78) showed no visible rings. In trunk samples, those proportions shifted towards $28 \%$ (36) with distinct rings, $31 \%$ (41) with indistinct and $41 \%$ (54) without rings.

The comparison of trunk- and branchwood of the same tree is given in Table 3 . In all cases, trunks had the same number or more samples with distinct rings than branches.

\section{Phenology}

Only 158 samples were used for this study due to the lack of information about leaf-shedding behaviour of other species. Among evergreen species $31 \%$ (28) of the samples have distinct rings, $23 \%$ (21) indistinct and $46 \%$ (41) show no growth rings. The proportion of distinct rings in semi-deciduous species is quite similar: $28 \%$ (19).

Table 3: Number of trunk- or branchwood samples with distinct growth rings.

\begin{tabular}{lcccc}
\hline Species & $\begin{array}{c}\text { Number of } \\
\text { branch samples }\end{array}$ & $\begin{array}{c}\text { Number of } \\
\text { branch samples } \\
\text { wih distinct rings }\end{array}$ & $\begin{array}{c}\text { Number of } \\
\text { trunk samples }\end{array}$ & $\begin{array}{c}\text { Number of } \\
\text { trunk samples } \\
\text { with distinct rings }\end{array}$ \\
\hline Blighia welwitschii & 5 & 5 & 4 & 4 \\
Carapa procera & 6 & 1 & 3 & 2 \\
Celtis mildbraedii & 5 & 5 & 4 & 4 \\
Chrysophyllum africanum & 5 & 1 & 3 & 1 \\
Cola griseiflora & 6 & 0 & 5 & 0 \\
Erythrophleum suaveolens & 5 & 2 & 3 & 2 \\
Garcinia punctata & 5 & 0 & 1 & 0 \\
Petersianthus macrocarpus & 5 & 3 & 6 & 0 \\
Polyalthia suaveolens & 6 & 3 & 5 & 5 \\
Pycnanthus angolensis & 5 & 2 & 4 & 4 \\
Staudtia kamerunensis & 5 & 4 & 4 & 4 \\
Trichilia gilgiana & 6 & 3 & 3 & 3 \\
Trilepisium madagascariense & 5 & 0 & 3 & 0 \\
\hline
\end{tabular}




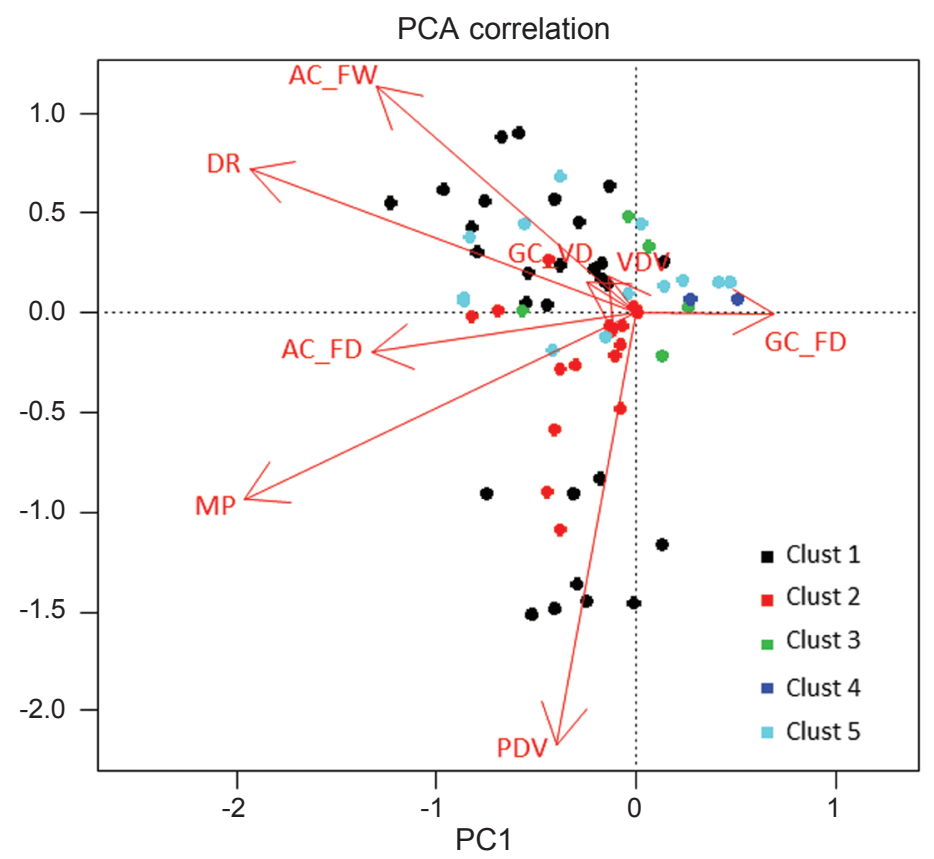

Figure 3. PCA of anatomical features defining growth rings. Correlations between 8 observed features mapped onto first two principal components. For abbreviations used see Table 1. Points represent individuals that belong to a particular cluster (see the paragraph "Clustering").

However, indistinct rings make up to $39 \%$ (27) of the samples and only $33 \%$ (23) show no rings.

\section{PCA of anatomical descriptors}

The PCA maps the anatomical features and individuals along the first two axes (Fig. 3). Three features contribute together to the first axis: changes in fibre dimensions correlated to marginal parenchyma and distended rays. Parenchyma density variation seems to be independent from the previous anatomical features and contributes mostly to the second axis. Finally, the changes related to vessel anatomy are not related to either of the first two axes.

Individuals from the first two clusters are widely spread across the correlation map. These clusters are composed of individuals with variable growth-ring anatomies. The other three clusters are more homogeneous. It should be noted that the proportion of the variance explained by the first two axes is relatively low (Table 4).

Table 4. Scores from the PCA. The first two axes explain $38 \%$ of the total variance.

\begin{tabular}{lcccccccc}
\hline & PC1 & PC2 & PC3 & PC4 & PC5 & PC6 & PC7 & PC8 \\
\hline Eigenvalue & 18.377 & 11.738 & 11.261 & 10.157 & 0.9699 & 0.853 & 0.66415 & 0.35951 \\
Proportion explained & 0.2297 & 0.1467 & 0.1408 & 0.127 & 0.1212 & 0.1066 & 0.08302 & 0.04494 \\
Cumulative proportion & 0.2297 & 0.3764 & 0.5172 & 0.6442 & 0.7654 & 0.872 & 0.95506 & 100.000 \\
\hline
\end{tabular}




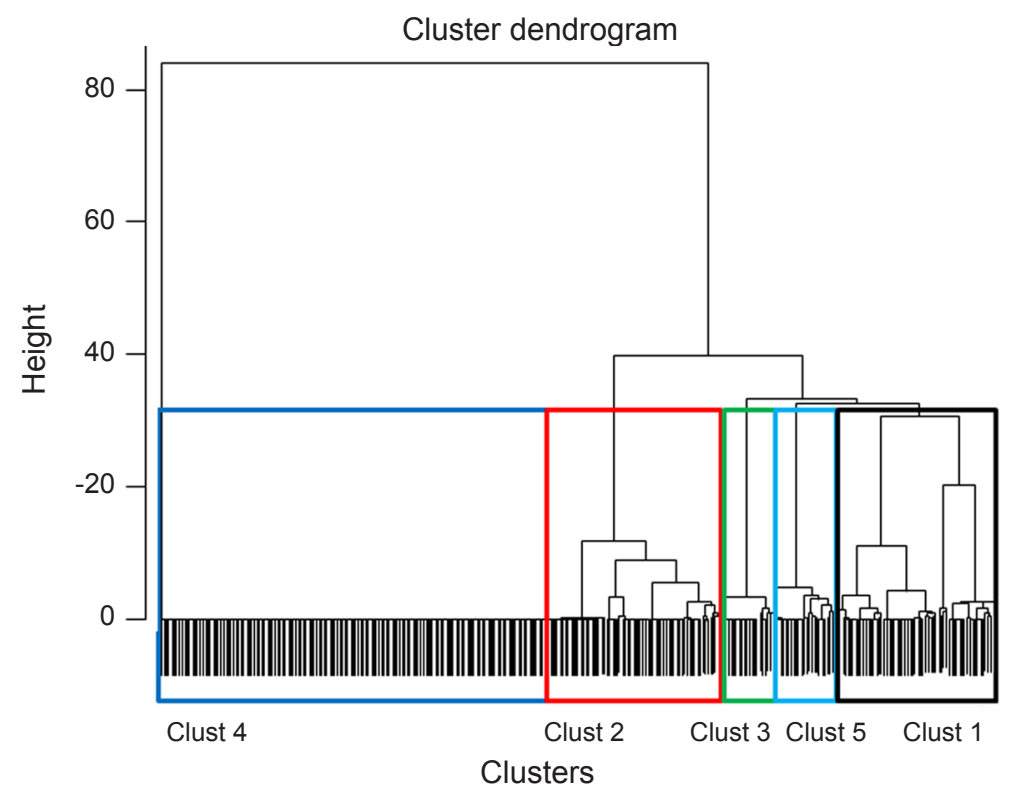

Figure 4: Cluster dendrogram with dissimilarity levels.

\section{Clustering}

Five groups of 62 (19\%), 68 (21\%), 20 (6\%), 150 (47\%) and $23(7 \%)$ individuals were created (Fig. 4). Clusters 1, 2, 3, and 5 are more closely related among each other than to cluster 4 .

The clusters were created based on the anatomical features defining their growth rings and an average was calculated for the occurrence of each anatomical descriptor for each group. The results are presented in Table 5. The first cluster is characterised by an important anatomical variability with individuals presenting abrupt changes in fibres, marginal parenchyma and distended rays. The majority of individuals have indistinct rings. The second cluster has mainly individuals with distinct growth rings defined by an abrupt change in fibre diameter, sometimes associated with marginal parenchyma and, to a lesser extent, distended rays. The third cluster is composed almost exclusively of individuals with indistinct rings characterised by gradual change in fibre diameter, sometimes associated with marginal parenchyma or distended rays. The fourth cluster

Table 5. Proportion of samples with studied anatomical features in each cluster. For abbreviations see Table 1.

\begin{tabular}{cccccccccccc}
\hline Cluster & AC_FW & AC_FD & GC_FD & GC_VD & VDV & MP & PDV & DR & distinct & indistinct & absent \\
\hline 1 & 0.381 & 0.219 & 0.016 & 0.028 & 0.032 & 0.630 & 0.298 & 0.516 & 0.359 & 0.641 & 0 \\
2 & 0 & 0.873 & 0 & 0 & 0.020 & 0.548 & 0.026 & 0.25 & 0.814 & 0.221 & 0 \\
3 & 0.025 & 0.05 & 0.925 & 0 & 0 & 0.15 & 0 & 0.125 & 0.05 & 0.95 & 0 \\
4 & 0 & 0 & 0.007 & 0 & 0 & 0 & 0 & 0 & 0.007 & 0.027 & 0.947 \\
5 & 0.152 & 0.264 & 0.076 & 0 & 0.994 & 0.348 & 0 & 0.087 & 0.319 & 0.681 & 0 \\
\hline
\end{tabular}


Table 6. Proportions of samples from different sites and different organs.

\begin{tabular}{lcccc}
\hline Cluster & Luki & Yangambi & Trunk & Branch \\
\hline 1 & $40 \%$ & $60 \%$ & $62 \%$ & $38 \%$ \\
2 & $49 \%$ & $51 \%$ & $52 \%$ & $48 \%$ \\
3 & $40 \%$ & $60 \%$ & $44 \%$ & $56 \%$ \\
4 & $39 \%$ & $61 \%$ & $41 \%$ & $59 \%$ \\
5 & $22 \%$ & $78 \%$ & $5 \%$ & $95 \%$ \\
Whole set & $40 \%$ & $60 \%$ & $45 \%$ & $55 \%$ \\
\hline
\end{tabular}

Table 7. Systematic affinity. Numbers of individuals of each family distributed in the five clusters.

\begin{tabular}{|c|c|c|c|c|c|}
\hline & Cluster 1 & Cluster 2 & Cluster 3 & Cluster 4 & Cluster 5 \\
\hline Anacardiaceae & & 4 & & 3 & \\
\hline Annonaceae & 9 & 9 & & 1 & 1 \\
\hline Apocynaceae & 3 & 6 & 2 & 8 & \\
\hline Asparagaceae & & & & 2 & \\
\hline Burseraceae & & & & 3 & \\
\hline Cannabaceae & & & 1 & 1 & \\
\hline Celastraceae & & 1 & & 7 & \\
\hline Chrysobalanaceae & & & & 4 & 1 \\
\hline Clusiaceae & & & & 4 & \\
\hline Connaraceae & 3 & 6 & 5 & 7 & \\
\hline Dichopetalaceae & 3 & 1 & & 16 & 9 \\
\hline Ebenaceae & & & & 3 & \\
\hline Euphorbiaceae & & 1 & 1 & 2 & \\
\hline Fabaceae & 17 & 14 & 4 & 22 & 1 \\
\hline Icacinaceae & & & & 3 & \\
\hline Irvingiaceae & & & 1 & 8 & \\
\hline Lamiaceae & & 1 & & 1 & 1 \\
\hline Linaceae & & 1 & & 2 & \\
\hline Malvaceae & 1 & & & 3 & \\
\hline Meliaceae & 10 & 4 & 1 & 5 & \\
\hline Moraceae & 1 & 1 & & 3 & \\
\hline Myristicaceae & & & 3 & & \\
\hline Olacaceae & & & 1 & 10 & \\
\hline Pandaceae & & & & 2 & \\
\hline Polygalaceae & & & & 1 & \\
\hline Rhamnaceae & & & & 3 & \\
\hline Rubiaceae & 4 & 3 & 1 & 16 & 7 \\
\hline Rutaceae & & 4 & & 4 & 3 \\
\hline Salicaceae & 2 & 2 & & & \\
\hline Sapindaceae & 1 & 6 & & 2 & \\
\hline Sapotaceae & 7 & 2 & & 4 & 1 \\
\hline Violaceae & 1 & 2 & & & \\
\hline
\end{tabular}


is made of individuals with no visible rings. Finally, the fifth cluster has the same proportions of distinct and indistinct rings as the first. Its principal anatomical feature is vessel density variation. Some of its individuals also show abrupt changes in fibres associated with marginal parenchyma.

The influence of climate, organ and phenology within clusters is presented in the next paragraphs. The results of Luki/Yangambi and trunk/branch repartition within different clusters are presented in Table 6.

The botanical families composing different clusters are presented in Table 7. A total of 32 families were represented in the sample set. Each family is present, on average, in 2.5 clusters. In our sample set, almost every family is represented in the cluster with absent growth rings. Families represented in only one or two clusters are mostly present in cluster 4 characterised by samples with no visible rings. Most of the families are characterised by a high variability of anatomical features marking the growth ring boundaries.

\section{Influence of the climate and tree organs}

The proportions of samples from Luki or Yangambi are similar to the proportion in the whole sample set in every cluster. The fifth cluster slightly differs from the other clusters and the whole sample set. The inter-cluster variability and the deviation from the average are higher in the Trunk-Branch proportions (Table 6).

Table 8. Proportion of samples with different phenological character in different clusters and in different sites.

\begin{tabular}{lc|cc}
\hline Cluster & Number of samples & Evergreen & Semi-deciduous \\
\hline 1 & $15(10 \%)$ & $40 \%$ & $60 \%$ \\
2 & $59(37 \%)$ & $51 \%$ & $49 \%$ \\
3 & $10(6 \%)$ & $50 \%$ & $50 \%$ \\
4 & $67(42 \%)$ & $64 \%$ & $36 \%$ \\
5 & $7(5 \%)$ & $86 \%$ & $14 \%$ \\
Whole set & 158 & $57 \%$ & $43 \%$ \\
\hline Yangambi & $71(45 \%)$ & $63 \%$ & $37 \%$ \\
Luki & $87(55 \%)$ & $52 \%$ & $48 \%$ \\
\hline
\end{tabular}

Table 9. Anatomy of growth rings in different clusters. The subset is composed of species with available information about their phenology. For abbreviations see Table 1.

\begin{tabular}{cccccccccccc}
\hline Cluster & AC_FW & AC_FD & GC_FD & GC_VD & VDV & MP & PDV & DR & distinct & indistinct & absent \\
\hline 1 & 0.9 & 0.355 & 0 & 0 & 0 & 0.667 & 0 & 0.733 & 0.7 & 0.3 & 0 \\
2 & 0.059 & 0.606 & 0.008 & 0.025 & 0.232 & 0.641 & 0 & 0.458 & 0.602 & 0.432 & 0 \\
3 & 0 & 0 & 1 & 0 & 0 & 0.1 & 0 & 0.1 & 0 & 1 & 0 \\
4 & 0 & 0 & 0 & 0 & 0 & 0 & 0 & 0 & 0.015 & 0.015 & 0.955 \\
5 & 0 & 0.143 & 0 & 0 & 0 & 0.714 & 0.857 & 0 & 0.143 & 0.857 & 0 \\
\hline
\end{tabular}




\section{Influence of the phenology}

The sample set is composed of 158 individuals of which 71 are from Yangambi and 87 from Luki. These two sites contribute equally to the group of individuals of evergreen species. The semi-deciduous species group is composed of $62 \%$ of individuals from Luki and $38 \%$ from Yangambi (Table 8). A new PCA and a new clustering were conducted on the 158 individuals subset and five subgroups were created from the subset of species with information on their leaf-shedding behaviour and their anatomy described (Table 9). The highest proportions of evergreen species are in clusters 4 and 5 where the highest proportions of indistinct or absent growth rings can be found. Cluster 1, with the highest proportion of distinct rings as well, has the highest proportion of semi-deciduous species. Cluster 2 is anatomically similar to cluster 1 but their species composition is different. There are more evergreen species in the second cluster than in the first.

Table 10 gives a more precise view about the contribution of evergreen and semideciduous species to the distinctness of growth rings. The only difference between Luki and Yangambi is that individuals with distinct rings are mostly evergreen species in Yangambi and semi-deciduous in Luki.

Table 10. Number of individuals with distinct, indistinct or absent rings in evergreen and semi-deciduous species groups in Luki and Yangambi. SD: semi-deciduous; E: evergreen.

\begin{tabular}{lcccc}
\hline & & Distinct & Indistinct & Absent \\
\hline \multirow{2}{*}{ Luki } & SD & $58 \%(14)$ & $57 \%(17)$ & $36 \%(12)$ \\
& E & $42 \%(10)$ & $43 \%(13)$ & $64 \%(21)$ \\
\hline \multirow{2}{*}{ Yangambi } & SD & $22 \%(5)$ & $56 \%(10)$ & $35 \%(11)$ \\
& E & $78 \%(18)$ & $44 \%(8)$ & $65 \%(20)$ \\
\hline
\end{tabular}

\section{DISCUSSION}

We observed variation in growth-ring anatomy between species, within species and even within individuals. These observations are in accordance with Fichtler and Worbes (2012). So far, growth-ring distinctness studies mainly focused on growth-ring boundaries distinctness on the species level without acknowledging possible intra-species variation (Worbes 1999; Groenendijk et al. 2014). Our study highlights the high level of variation of growth-ring anatomy and distinctness in the tropics and raises questions about the sources of this variation. Here, we address some of these questions.

By analysing the results of clustering on Figure 4 we can observe that clusters 1, 3 and 5 have very small dissimilarity levels. Moreover, counting them as only one cluster would enable us to work with three different clusters: one cluster with a majority of distinct growth rings, one with a majority of indistinct and one with absent growth rings. However, most of the variability lies within these three groups and considering them as one unique cluster would prevent several analyses provided in the upcoming paragraphs. 


\section{Influence of the climate on growth-ring distinctness}

In our sample set, the proportion of trees with distinct, indistinct or invisible rings is similar in Luki and Yangambi. Moreover, the relative proportions of individuals from Luki and Yangambi remain similar in four groups out of five. Only cluster 5, with only 23 individuals, has different proportions (22\% from Luki and $78 \%$ from Yangambi). This cluster is dominated by samples with indistinct rings defined by vessel density variations (areas with very few or even without vessels throughout the samples). This could be linked to water availability (Zanne et al.2010). However, most of the individuals with these features are originating from Yangambi which shows a more uniform precipitation distribution than Luki. It is to be noted that the size of the sample subset might play a role and that the percentage share might not be representative of a larger population with these anatomical characteristics.

Cluster 2, larger than the previous (68 individuals), also deviates from the overall proportions Luki/Yangambi. Individuals from Luki make up to $49 \%$ of cluster 2 (against $40 \%$ in the total sample set). This cluster is characterised by individuals with distinct growth rings showing abrupt changes in radial fibre diameter. The increase in the proportion of samples from Luki in this cluster is in accordance with the hypothesis that a stronger seasonality leads trees to the formation of more distinct growth rings. Accord-ing to Borchert (1999), plants react to drought but responses vary widely among trees and their annual development is not well synchronised by climatic seasonality. Also, the length of the dry season may not be sufficient as a proxy for water availability. Soils with a better water retention or sites with higher relative air humidity levels can create conditions that satisfy the trees' water needs and buffer a longer dry season (Borchert 1999).

Luki and Yangambi differ in terms of annual rainfall and the length of the dry season but other factors such as a constantly high relative humidity in Luki can make up for the decrease in rainfall during several months. Finally, according to Fichtler and Worbes (2012), a greater variability is observed between individuals at one site rather than between different sites. Although the number of studied individuals is limited, our observations appear to be in line with Fichtler and Worbes' findings (Tables 5 \& 6). This may indicate that cambial activity is more sensitive to climatic variability from year to year than to the average climate conditions per site.

It is also important to keep in mind that our study is a general overview of different individuals in two contrasting sites. It gives us a first insight of the possible trends but there is no precise information about the response of a single species to different climatic conditions. In several species, individuals came from only one site and, in general, not enough individuals per species per site were available for a thorough analysis of within-species response to the climate. An adapted sampling design with enough replications per species per site is necessary to effectively tackle the question of the behaviour of growth-ring distinctness under the influence of climate within the tropics.

\section{Influence of the organs on growth-ring distinctness}

A bigger variability is observed among clusters in terms of branch/trunk proportions in the samples. Trunk sample proportion shifts from $62 \%$ in the first cluster to 
$5 \%$ in the last one. Data suggest that a slightly higher proportion of distinct rings is to be found in trunkwood (cluster 2 defined by distinct rings has a higher proportion of trunk samples). Features like abrupt change in fibre diameter or wall thickness, marginal parenchyma or distended rays seem to occur more often in trunkwood than in branches. Storage tissues associated with growth-ring boundaries are thus more evident in trunks than in branches. As cambial activity normally starts nearby the site of photosynthesis and moves further down the trunk (Tepper \& Hollis 1967), storage tissues in the trunk may be useful to resume stem cambial activity faster by using reserves stored close to the cambium layer. However, a very limited number of species present both branch- and trunkwood in our samples set. In some species trunks present a lot of storage tissues while branches do not (Hylodendron gabunense, Trichilia prieuriana, Zanthoxylum gilletii), in some species the contrary can be observed (Chytranthus macrobotrys, Maranthes glabra), some species have abundant storage tissues in both trunks and branches (Synsepalum subcordatum) and some species do not show storage tissues at growth-ring boundaries regardless of the organ (Klainedoxa gabonensis, Oncoba welwitschii, Strombosia grandifolia).

We can also note that the fifth cluster is largely dominated by branchwood. Branchwood tends to show more variation in the vessel density than trunkwood according to our results. Tree water status is an important variable controlling phenology and cambium activity (Borchert 1999). Vessel conductivity is function of the size and number of vessels per unit area (Zanne et al. 2010). To avoid important moisture losses by transpiration during dry periods, branches with zones of a lower vessel density might be one of the solutions adopted by tropical trees.

We can also take into account the third and fourth clusters. They are defined by samples with indistinct or absent growth rings and share almost exactly the same proportions of trunk/branchwood as in the whole sample set. We can conclude that a tree with distinct growth rings in the trunk might still have indistinct rings in the branches. On the other hand, if rings are indistinct or simply absent in the trunkwood, it is improbable to find distinct rings in the branches. This statement is supported by our results in Table 3.

However, the scientific potential of growth rings in the branchwood must not be underestimated. Nicolini et al. (2012) have studied growth rings in branchwood of a tropical species (Parkia velutina) and could date with a reasonable error the age of the tree. Further research is needed to fully assess the potential of branchwood in growthring studies and possibly use branch rings to reconstruct tree growth.

\section{Influence of phenology}

The original phenological observations were carried out between 1948 and 1957 and brevi-deciduousness was not taken into account (Couralet et al. 2010) which meant that trees being observed leafless for more than 10 days during the observation period were marked as being deciduous. To avoid such sweeping generalisations we limited our analyses to "evergreen" and "semi-deciduous" species. This category is coarser but is better adapted from an ecological point of view to our sample set and available information. 
Our observations about the influence of leaf phenology on growth-ring distinctness in the 158 individuals reveal interesting trends. The share of individuals of semi-deciduous species is the highest in clusters with the most distinct rings while evergreen species are more represented in the clusters with a majority of indistinct or absent rings. This is in accordance with the previous statements that growth-ring distinctness is linked to tree phenology (Worbes 1999; Borchert 1999; Brienen \& Zuidema 2005). However, Table 10 shows us that within the group of individuals with distinct rings in Luki, the share of individuals of semi-deciduous species (58\%) is much higher than in Yangambi $(22 \%)$. For individuals with indistinct or absent rings, proportions of semi-deciduous species remain the same in Luki and Yangambi. This is supported by Worbes' statements that not all deciduous species form distinct rings (Worbes 1999). According to Borchert (1999), phenology and cambial growth are correlated with each other in tropical dry climates and get progressively uncoupled with the increase in precipitation. This difference in semi-deciduous species proportions between individuals with distinct or indistinct/absent rings might thus be in accordance with the longer dry season recorded in Luki and the low storage capacity in its soils (FAO 1979). This may also explain the relatively high cumulated proportion (72\%) of samples with indistinct and absent rings in the semi-deciduous species in the whole sample set.

However, we must keep in mind that our sample set does not allow for testing climate influence on leaf shedding behaviour at the individual level (which was not the goal of this study). Based on the observations conducted in Luki, we assigned the evergreen or semi-deciduous character to the species as a whole, which may be incorrect for the two contrasting sites.

\section{Remaining problems and future research for growth-ring distinctness}

Although our sample set contains many individuals representing a considerable number of species, it is important to keep in mind that some limitations exist. The Xylarium samples are most often variable in size and metadata are not very precise; some of them are cubes of c. $2 \times 2 \times 2 \mathrm{~cm}$ with no indication of their position within the trunk. Most of the samples used for this study were only a few centimetres long. Although the absence of distinct or indistinct growth rings in those samples is valuable information about anatomical and growth trends, it does not provide the information about possible growth rings in other parts of the trunk. Moreover, even if growth rings are visible, we possibly describe only a part of their variability and know little about growth-ring anatomy variation over the years. This is especially true if only few samples are available. To avoid the lack of representativeness, we recommend studying growth-ring distinctness and variability on pith-to-bark cores or complete disks.

It is also important to consider the link between "distinct" or "indistinct" tag and growth-rings anatomy. During this study, we focused on distinctness understood as abrupt changes in fibre diameter and/or wall thickness. This raised several problems during the process. First of all, the IAWA definition of distinct growth ring boundaries uses the adverb "usually" when referring to changes in fibre wall thickness and/ or radial diameter. We believe that in the tropical context, this definition emphasises too much the changes in fibres anatomy compared to other descriptors. The term 
"usually" might lead to an underestimation of the proportion of species with distinct rings in the tropics. Moreover, the meaning of "indistinct" is vague and an arbitrary one (as is the separation of "indistinct" and "absent"" as judged from the illustrations in the Hardwood List). In several cases in our material, boundaries were defined by parenchyma patterns (parenchyma bands variation in size or frequency, parenchyma cell shape), vessel organisation (same size but vessels aligned in a tangential row) or distended rays associated with more-or-less gradual variation in fibre anatomy. We classified these structures as indistinct growth rings when they were not accompanied by abrupt changes in fibres anatomy. We think that a more flexible approach in classifying tropical growth-ring distinctness while providing a rigorous methodology in growth ring research is possible. The ability to tell whether a single cell belongs to the $\mathrm{Nth}$ or the $\mathrm{N}+1$ th ring should be emphasised. A quantitative assessment of growth-ring distinctness could also be elaborated (e.g., a measurement of the distance between consecutive parenchyma bands, high-resolution densitometry or parenchyma cell measurements). Schweingruber et al. (2006) propose a more complete description of growth-ring distinctness with attention paid to the possibility to cross-date rings and conduct dendrochronological studies.

Growth-ring distinctness needs further research to be used as a trait in ecological studies. A consensus on different levels of distinctness needs to be reached among scientists and classification must be as objective as possible. A measure of the degree of distinctness (e.g., the amplitude of variation of radial fibre diameter) can be implemented to measure the sensitivity of trees to variable environmental conditions. This can complement the previously researched features like ring width (Worbes 1999) or the variation in vessel pattern (Fichtler \& Worbes 2012). To comply with Lachenbruch and McCulloh's (2014) definition, a time frame for the analyses also needs to be defined. Since the feature is supposed to maintain the same value over the study period, a period representative of different life stages (juvenile, mature, old) of trees needs to be defined per species.

It is important for further dendrochronological and dendroecological studies to take into account the possible geographical variation in growth-ring distinctness in different databases. To assess the annual nature of growth zones boundaries and consider them as growth rings, additional studies as cambial marking, cross-dating, radiocarbon (Rozendaal \& Zuidema 2011), oxygen isotopes (Poussart et al. 2004) or calcium (Poussart et al. 2006) measurements might be necessary in case of doubt. Finally, we need to understand growth-ring diversity and escape the artificial binary vision of distinct versus indistinct to absent growth rings.

\section{ACKNOWLEDGEMENTS}

We are grateful to the FRIA (FNRS), the Belspo and the ERAIFT for support and funding. We also would like to thank K. Lievens for preparing the thin sections and J.C.Cerre for showing us his technique in wood surface polishing. We are very grateful to the local community chiefs from DRC and the local staff that considerably facilitated our work on the field. Finally we express our gratitude to the members of COST Action STReESS (COST-FP1106). 


\section{REFERENCES}

Baas P. 1982. Leeuwenhoek's contributions to wood anatomy and his ideas on sap transport in plants. pp. 79-107 in: Palm LC \& Snelders HAM (eds.), Antoni van Leeuwenhoek 16321982. Rodopi, Amsterdam.

Baas P \& Vetter RE. 1989. Growth rings in tropical trees. IAWA Bull. n.s. 10: 95-174.

Bastin JF, Fayolle A, Tarelkin Y, Van den Bulcke J, De Haulleville T, Mortier F, Beeckman H, Van Acker J, Bogaert J \& De Cannière C. 2015. Wood specific gravity variations and biomass of Central African tree species: the simple choice of the outer wood. PloS ONE 10 (11), e 0142146 .

Beeckman H. 2016. Wood anatomy and trait-based ecology. IAWA J. 37: 127-151.

Borchert R. 1999. Climatic periodicity, phenology, and cambium activity in tropical dry forest trees. IAWA J. 20: 239-247.

Bräuning A, De Ridder M, Zafirov N, García-González I, Dimitrov DP \& Gärtner H. 2016. Tree-ring features - indicators of extreme event impacts. IAWA J. 37: 206-231.

Brienen RJ \& Zuidema PA. 2005. Relating tree growth to rainfall in Bolivian rain forests: a test for six species using tree ring analysis. Oecologia 146: 1-12.

Carlquist S. 2001. Comparative wood anatomy: systematic ecological, and evolutionary aspects of dicotyledon wood. Springer-Verlag, Berlin. 448 pp.

Cherubini P, Humbel T, Beeckman H, Gärtner H, Mannes D, Pearson C, Schoch W, Tognetti R \& Lev-Yadun S. 2013. Olive tree-ring problematic dating: a comparative analysis on Santorini (Greece). PloS ONE 8 (1), e 54730.

Cornelissen JHC, Lavorel S, Garnier E, Diaz S, Buchmann N, Gurvich DE, Reich PB, ter Steege H, Morgan HD, Van der Heijden MGA, Poorter H \& Pausas JG. 2003. A handbook of protocols for standardised and easy measurement of plant functional traits worldwide. Austral. J. Bot. 51: 335-380.

Couralet C, Sterck FJ, Sass-Klaassen U, Van Acker J \& Beeckman H. 2010. Species-specific growth responses to climate variations in understory trees of a Central African rain forest. Biotropica 42: 503-511.

De Micco V, Campelo F, De Luis M, Bräuning A, Grabner M, Battipaglia G \& Cherubini P. 2016. Intra-annual density fluctuations in tree rings: how, when, where and why? IAWA J. 37: 232-259.

De Ridder M, Trouet V, Van den Bulcke J, Hubau W, Van Acker J \& Beeckman H. 2013. A tree-ring based comparison of Terminalia superba climate-growth relationships in West and Central Africa. Trees 27: 1225-1238.

Donis C. 1948. Essai d'économie forestière au Mayumbe. INEAC, Bruxelles, Belgium.

Fahn A. 1962. Xylem structure and the annual rhythm of cambial activity in woody species of the East Mediterranean regions. News Bull. Int. Ass. Wood Anat. 1962: 2-6.

FAO. 1979. Management properties of ferralsols. FAO Soils Bull. 23. FAO, Rome.

FAO. 2007. Digital soil map of the world. FAO, Rome.

Fichtler E \& Worbes M. 2012. Wood anatomical variables in tropical trees and their relation to site conditions and individual tree morphology. IAWA J. 33: 119-140.

Fonti P, von Arx G, García-González I, Eilmann B, Sass-Klaassen U, Gärtner H \& Eckstein D. 2010. Studying global change through investigation of the plastic responses of xylem anatomy in tree rings. New Phytologist 185: 42-53.

Francis JE \& Hill RS. 1996. Fossil plants from the Pliocene Sirius Group, Transantarctic Mountains: evidence for climate from growth rings and fossil leaves. Palaios 11: 389-396.

Gärtner H \& Nievergelt D. 2010. The core-microtome: a new tool for surface preparation on cores and time series analysis of varying cell parameters. Dendrochronologia 28: 85-92. 
Gilson P. 1956. Map of soils and vegetation of the Belgian Congo and Ruanda-Urundi. Explanatory note. 6. Yangambi. Survey 2: Yangambi. Publications de l'Institut National pour l'Etude Agronomique du Congo Belge.

Gourlay ID. 1995. The definition of seasonal growth zones in some African Acacia species - a review. IAWA J. 16: 353-359.

Groenendijk P, Sass-Klaassen U, Bongers F \& Zuidema PA. 2014. Potential of tree-ring analysis in a wet tropical forest: a case study on 22 commercial tree species in Central Africa. Forest Ecology and Management 323: 65-78.

Hubau W, Van den Bulcke J, Van Acker J \& Beeckman H. 2015. Charcoal-inferred Holocene fire and vegetation history linked to drought periods in the Democratic Republic of Congo. Global Change Biology 21: 2296-2308.

IAWA Committee. 1989. IAWA list of microscopic features for hardwood identification. IAWA Bull. n.s. 10: 219-332.

Kearsley E, de Haulleville T, Hufkens K, Kidimbu A, Toirambe B, Baert G, Huygens D, Kebede Y, Defourny P, Bogaert J \& Beeckman H. 2013. Conventional tree height-diameter relationships significantly overestimate aboveground carbon stocks in the Central Congo Basin. Nature Communications 4: 2269.

Lachenbruch B \& McCulloh KA. 2014. Traits, properties, and performance: how woody plants combine hydraulic and mechanical functions in a cell, tissue, or whole plant. New Phytologist 204: 747-764.

Lebrun J \& Gilbert G. 1954 Une classification écologique des forêts du Congo. INEAC, Série Scientifique No. 63, Bruxelles.

McBride JR. 1983. Analysis of tree rings and fire scars to establish fire history. Tree-Ring Bull. 43: 51-67.

Nicolini E, Beauchêne J, de la Vallée BL, Ruelle J, Mangenet T \& Heuret P. 2012. Dating branch growth units in a tropical tree using morphological and anatomical markers: the case of Parkia velutina Benoist (Mimosoideae). Ann. For. Sci. 69: 543-555.

Peel MC, Finlayson BL \& McMahon TA. 2007. Updated world map of the Köppen-Geiger climate classification. Hydrology and Earth System Sciences Discussions 4: 439-473.

Pérez-Harguindeguy N, Díaz S, Garnier E, Lavorel S, Poorter H, Jaureguiberry P, BretHarte MS, Cornwell WK, Craine JM, Gurvich DE, Urcelay C, Veneklaas EJ, Reich PB, Poorter L, Wright IJ, Ray P, Enrico L, Pausas JG, de Vos AC, Buchmann N, Funes G, Quétier F, Hodgson JG, Thompson K, Morgan HD, ter Steege H, van der Heijden MGA, Sack L, Blonder B, Poschlod P, Vaieretti MV, Conti G, Staver AC, Aquino S \& Urcelay C. 2013. New handbook for standardised measurement of plant functional traits worldwide. Austral. J. Bot. 61: 167-234.

Poussart PF, Evans MN \& Schrag DP. 2004. Resolving seasonality in tropical trees: multi-decade, high-resolution oxygen and carbon isotope records from Indonesia and Thailand. Earth and Planetary Science Letters 218: 301-316.

Poussart PM, Myneni SCB \& Lanzirotti A. 2006. Tropical dendrochemistry: A novel approach to estimate age and growth from ringless trees. Geophys. Res. Lett. 33: 1-5.

Rozendaal DM \& Zuidema PA. 2011. Dendroecology in the tropics: a review. Trees 25: 3-16. Schierbeek A. 1959. Measuring the invisible world: the life and works of Antoni van Leeuwenhoek (No. 37). Abelard-Schuman Ltd, London.

Schweingruber FH. 1996. Tree rings and environment: dendroecology. Paul Haupt AG, Bern. 609 pp. 
Schweingruber FH, Börner A \& Schulze ED. 2006. Atlas of woody plant stems: evolution, structure, and environmental modifications. Springer, Heidelberg. 229 pp.

Sonsin JO, Gasson PE, Barros CF \& Marcati CR. 2012. A comparison of the wood anatomy of 11 species from two cerrado habitats (cerrado ss and adjacent gallery forest). Bot. J. Linn. Soci. 170: 257-276.

Studhalter RA, Glock WS \& Agerter SR. 1963. Tree growth, some historical chapters in the study of diameter growth. Bot. Review 29: 245-343.

Tarhule A \& Hughes MK. 2002. Tree-ring research in semi-arid West Africa: need and potential. Tree-Ring Research 58: 31-46.

Tepper HB \& Hollis CA. 1967. Mitotic reactivation of the terminal bud and cambium of white ash. Science 156 (3782): 1635-1636.

Van den Bulcke J, Boone M, Van Acker J, Stevens M \& Van Hoorebeke L. 2009. X-ray tomography as a tool for detailed anatomical analysis. Ann. For. Sci. 66: 1-12.

Van Ranst E, Baert G, Ngongo M \& Mafuka P. 2010. Carte pédologique de Yangambi, planchette 2: Yangambi, échelle 1:50.000. Published by UGent, Hogent, Ghent, Belgium.

Venegas-González A, von Arx G, Chagas MP \& Tomazello Filho M. 2015. Plasticity in xylem anatomical traits of two tropical species in response to intra-seasonal climate variability. Trees 29: 423-435.

Violle C, Navas ML, Vile D, Kazakou E, Fortunel C, Hummel I \& Garnier E. 2007. Let the concept of trait be functional! Oikos 116: 882-892.

Whitmore TC. 1998. An introduction to tropical rain forests. Oxford University Press, Oxford, UK.

Wils TH, Robertson I, Eshetu Z, Sass-Klaassen UG \& Koprowski M. 2009. Periodicity of growth rings in Juniperus procera from Ethiopia inferred from crossdating and radiocarbon dating. Dendrochronologia 27: 45-58.

Worbes M. 1995. How to measure growth dynamics in tropical trees a review. IAWA J. 16: 337-351.

Worbes M. 1999. Annual growth rings, rainfall-dependent growth and long-term growth patterns of tropical trees from the Caparo Forest Reserve in Venezuela. J. Ecol. 87: 391-403.

Worbes M \& Fichtler E. 2010. Wood anatomy and tree-ring structure and their importance for tropical dendrochronology. In: Junk WJ, Piedade MTF, Wittmann F, Schöngart J \& Parolin P (eds.), Amazonian floodplain forests: ecophysiology, biodiversity and sustainable management: 329-346. Springer, Berlin, Heidelberg, New York.

Zanne AE, Westoby M, Falster DS, Ackerly DD, Loarie SR, Arnold SE \& Coomes DA. 2010. Angiosperm wood structure: global patterns in vessel anatomy and their relation to wood density and potential conductivity. Amer. J. Bot. 97: 207-215.

Accepted: 8 April 2016 
Supplementary data for:

\title{
GROWTH-RING DISTINCTNESS AND BOUNDARY ANATOMY VARIABILITY IN TROPICAL TREES
}

\author{
Yegor Tarelkin ${ }^{1,2, *}$, Claire Delvaux ${ }^{2}$, Maaike De Ridder $^{2}$, Thomas El Berkani $^{1}$, \\ Charles De Cannière ${ }^{1}$, and Hans Beeckman ${ }^{2}$ \\ ${ }^{1}$ Landscape Ecology and Plant Production Systems Unit, Université libre de Bruxelles, CP 264/2, \\ 1050 Bruxelles, Belgium \\ ${ }^{2}$ Wood Biology Service, Royal Museum for Central Africa (RMCA), Leuvensesteenweg 13, \\ 3080 Tervuren, Belgium \\ *Corresponding author: yegor.tarelkin@ulb.ac.be
}

\section{Content: Supplementary Annex 1}




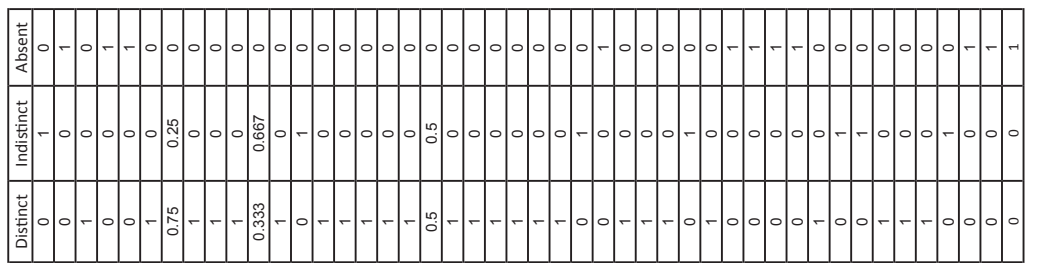

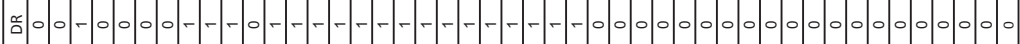

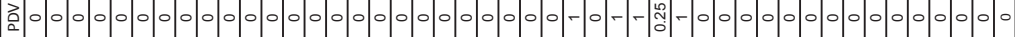

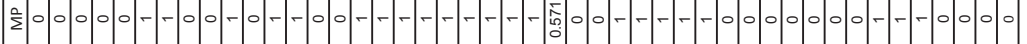

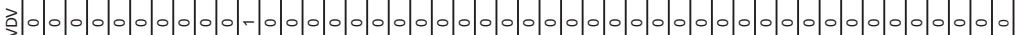
9 0 o 0 ড)

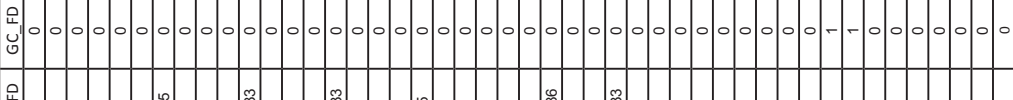

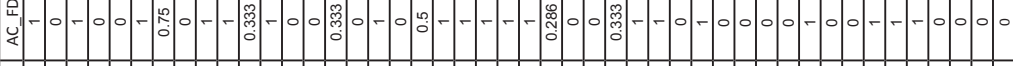

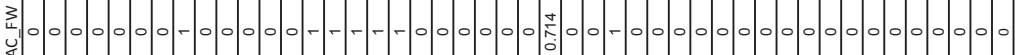
喜 :

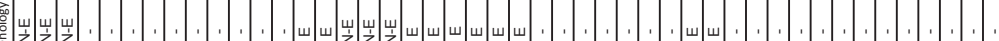

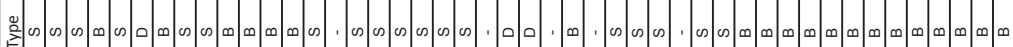

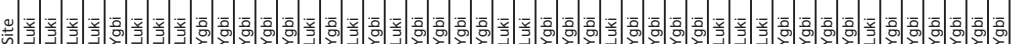

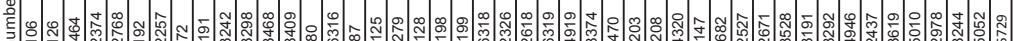
定

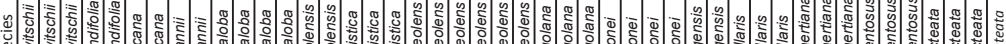

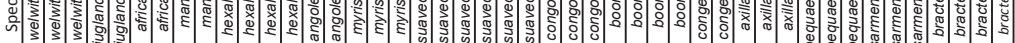




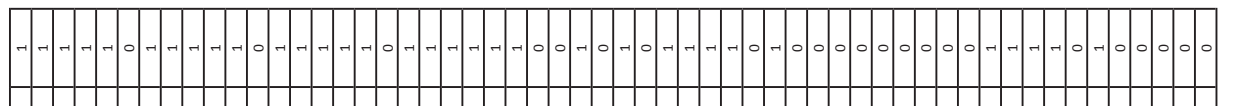

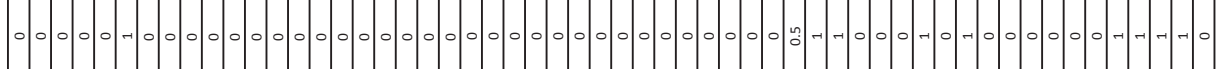

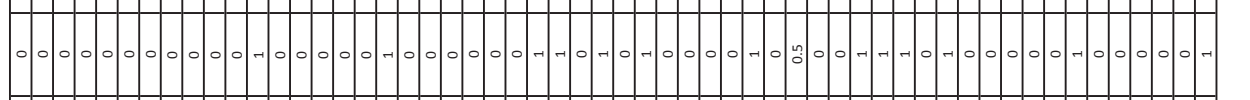

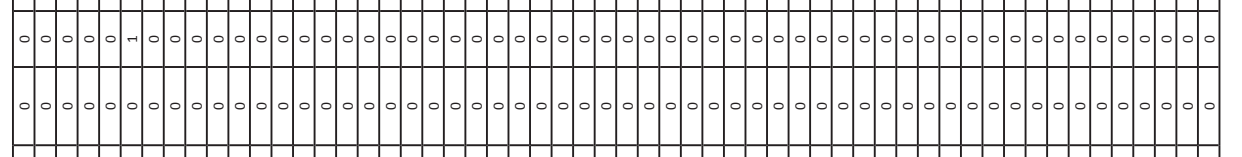

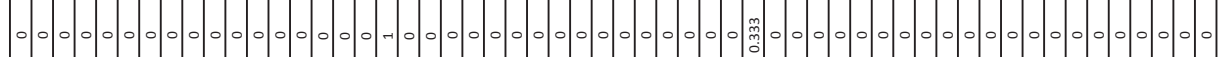

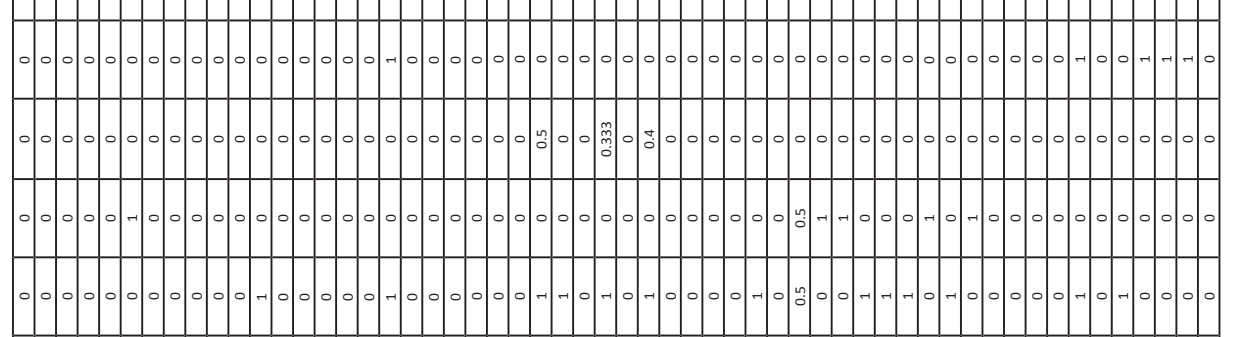

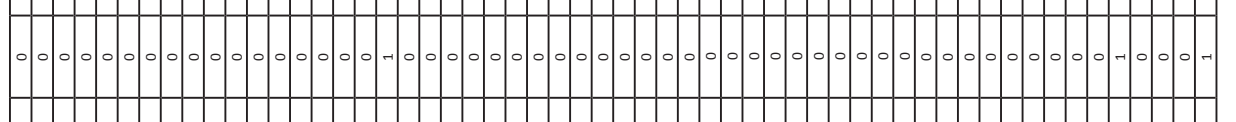

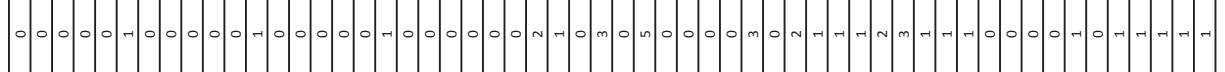

$\ddot{z} \ddot{z} \dot{z} \omega \mid$

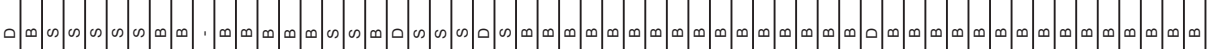

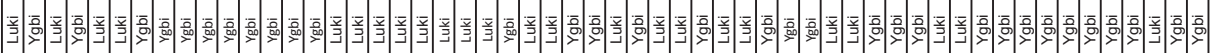

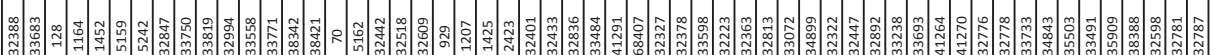

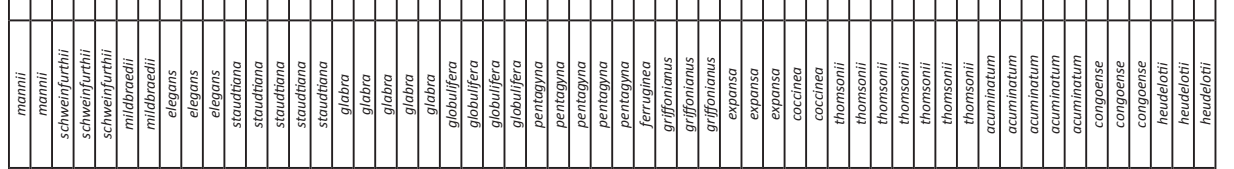

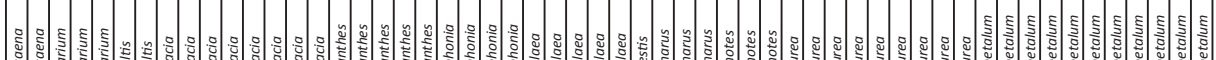

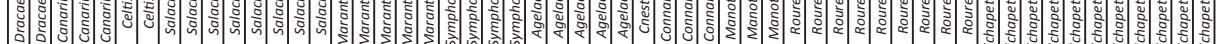

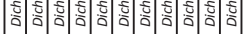

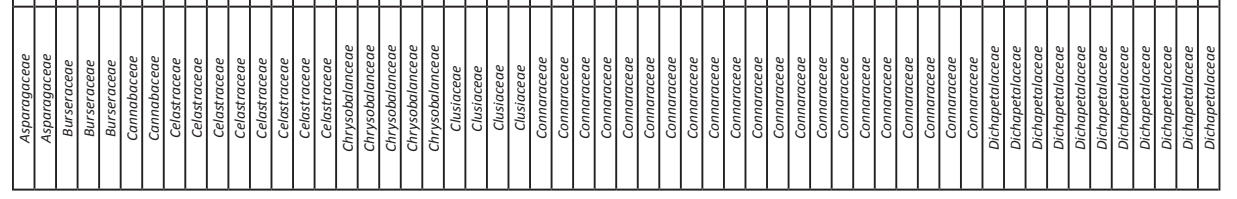




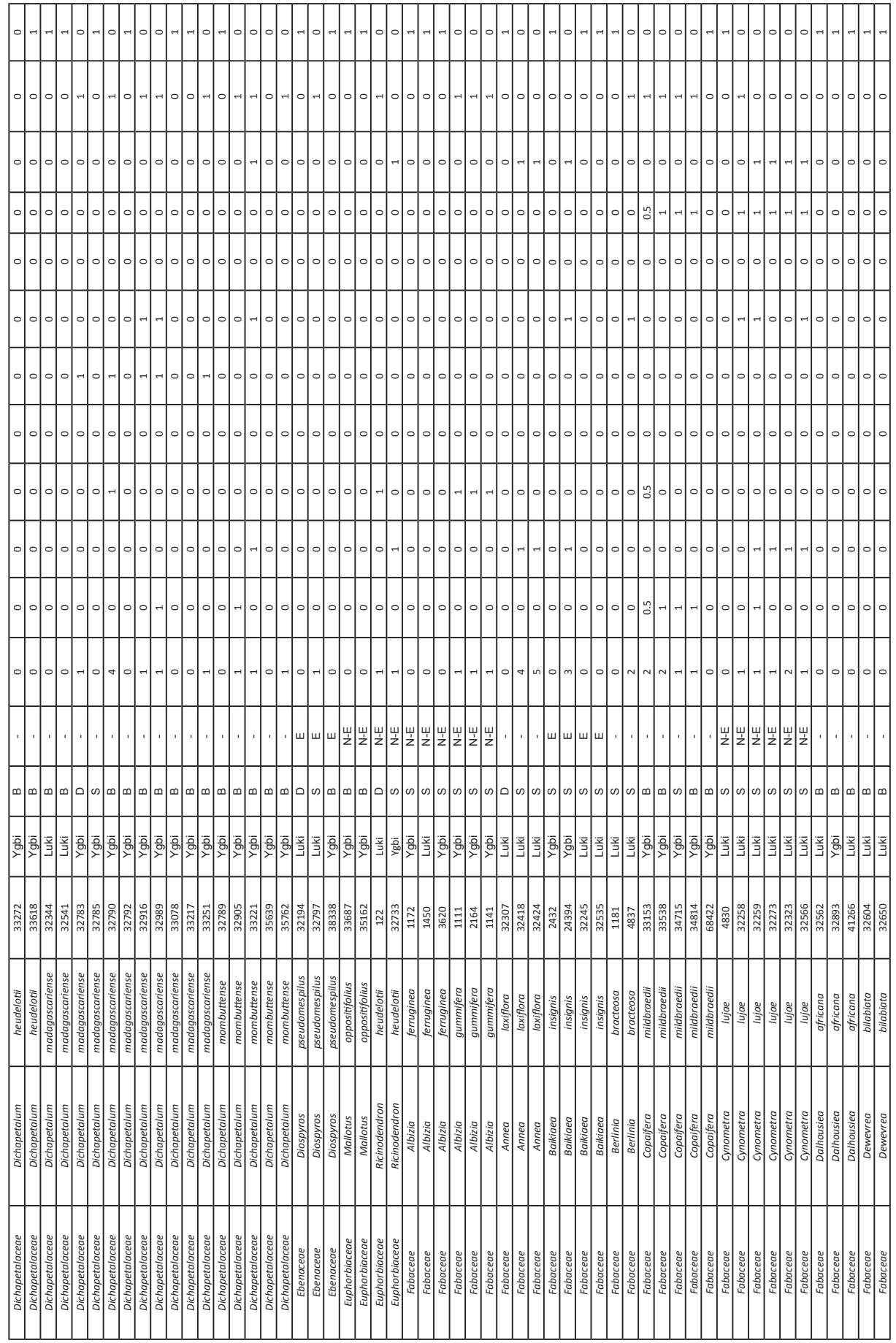




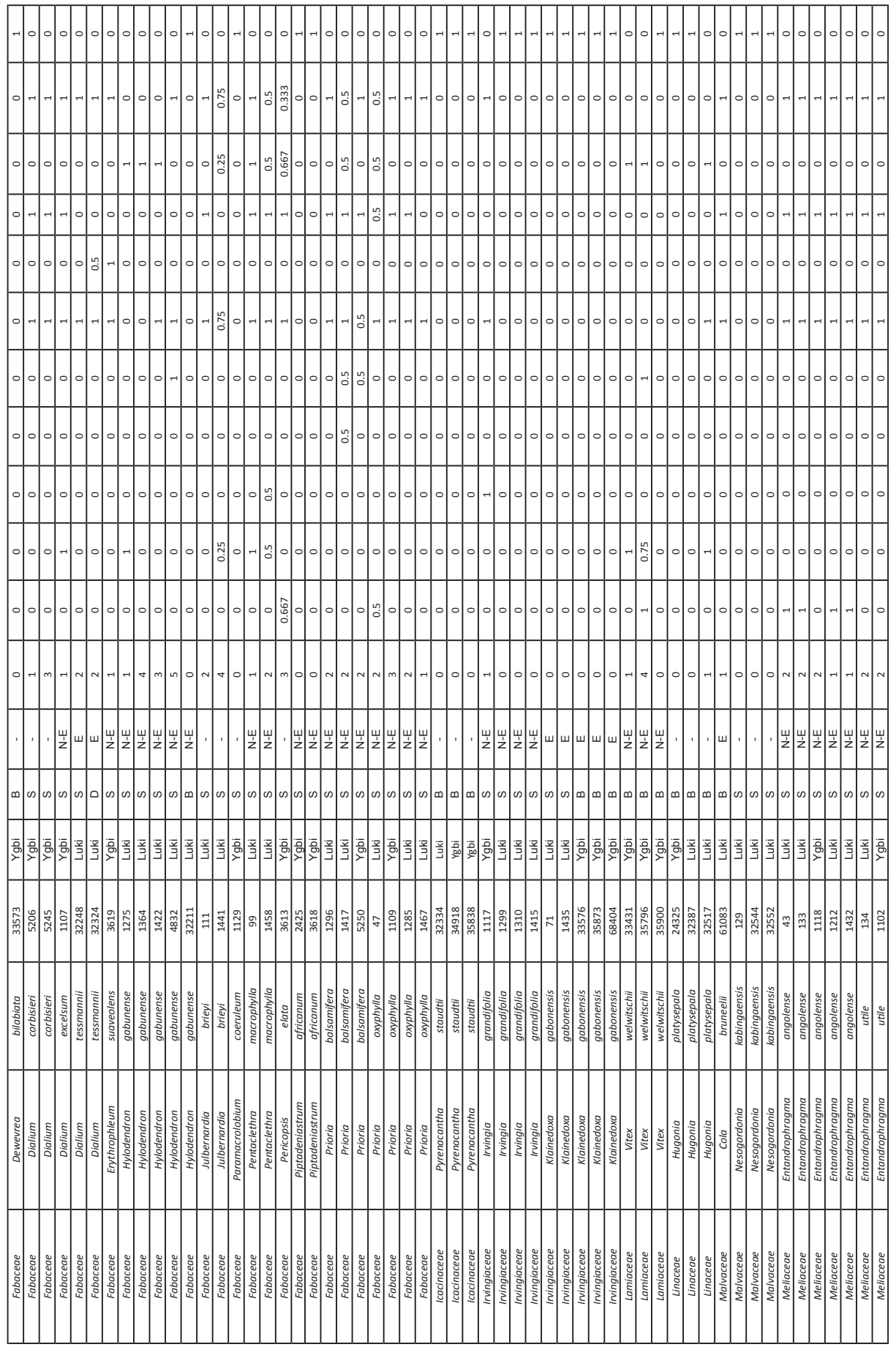




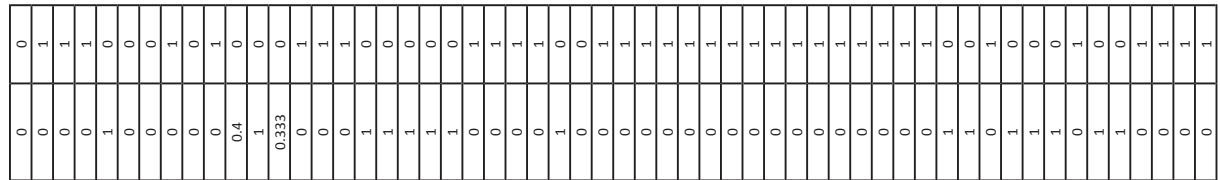

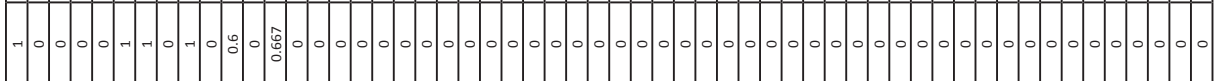

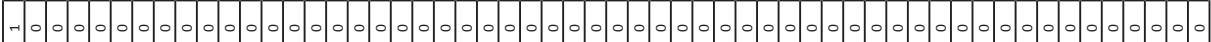

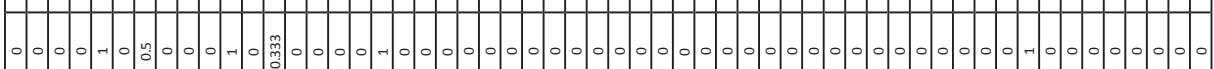

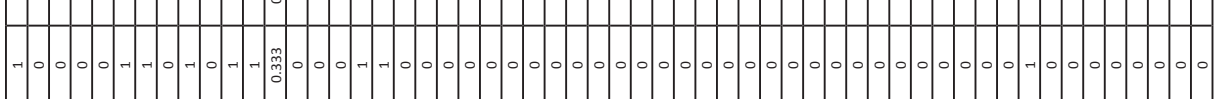

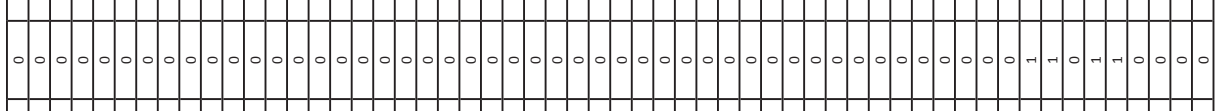

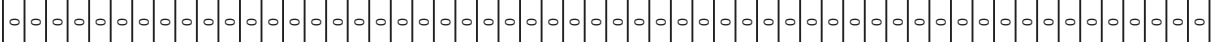

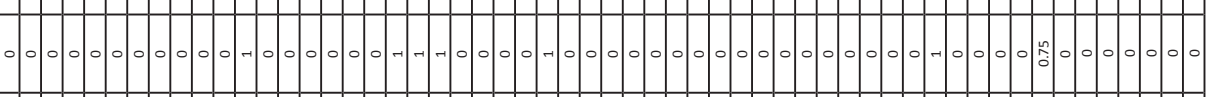

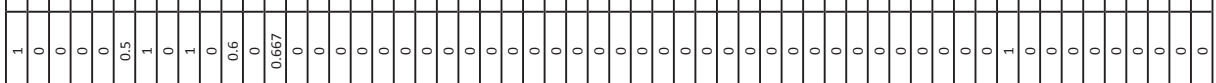

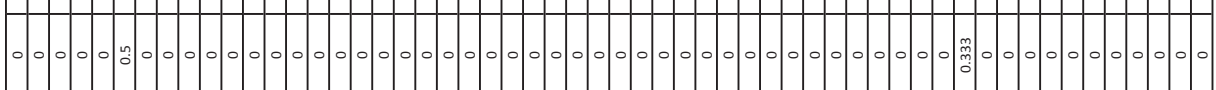

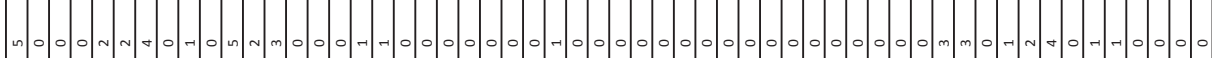

$\underline{m}$

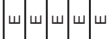

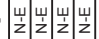

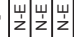

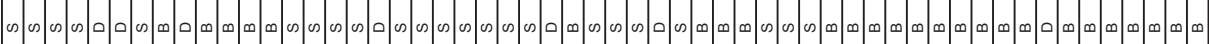

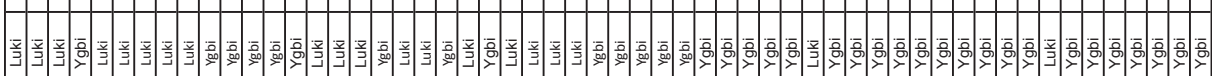

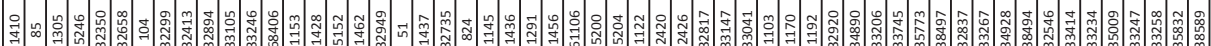

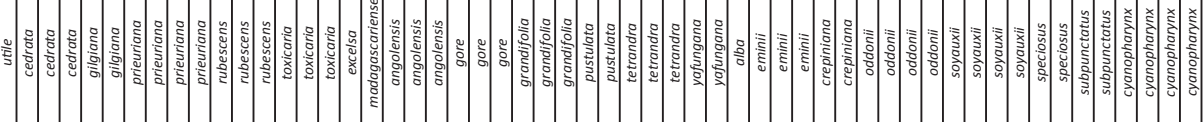

हूँ

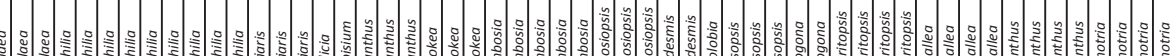

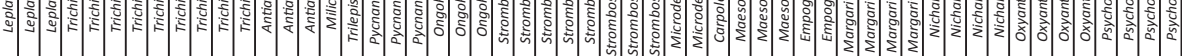
空

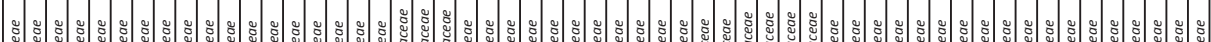

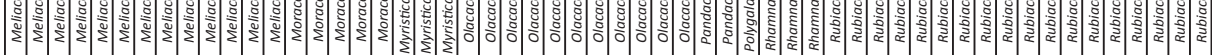




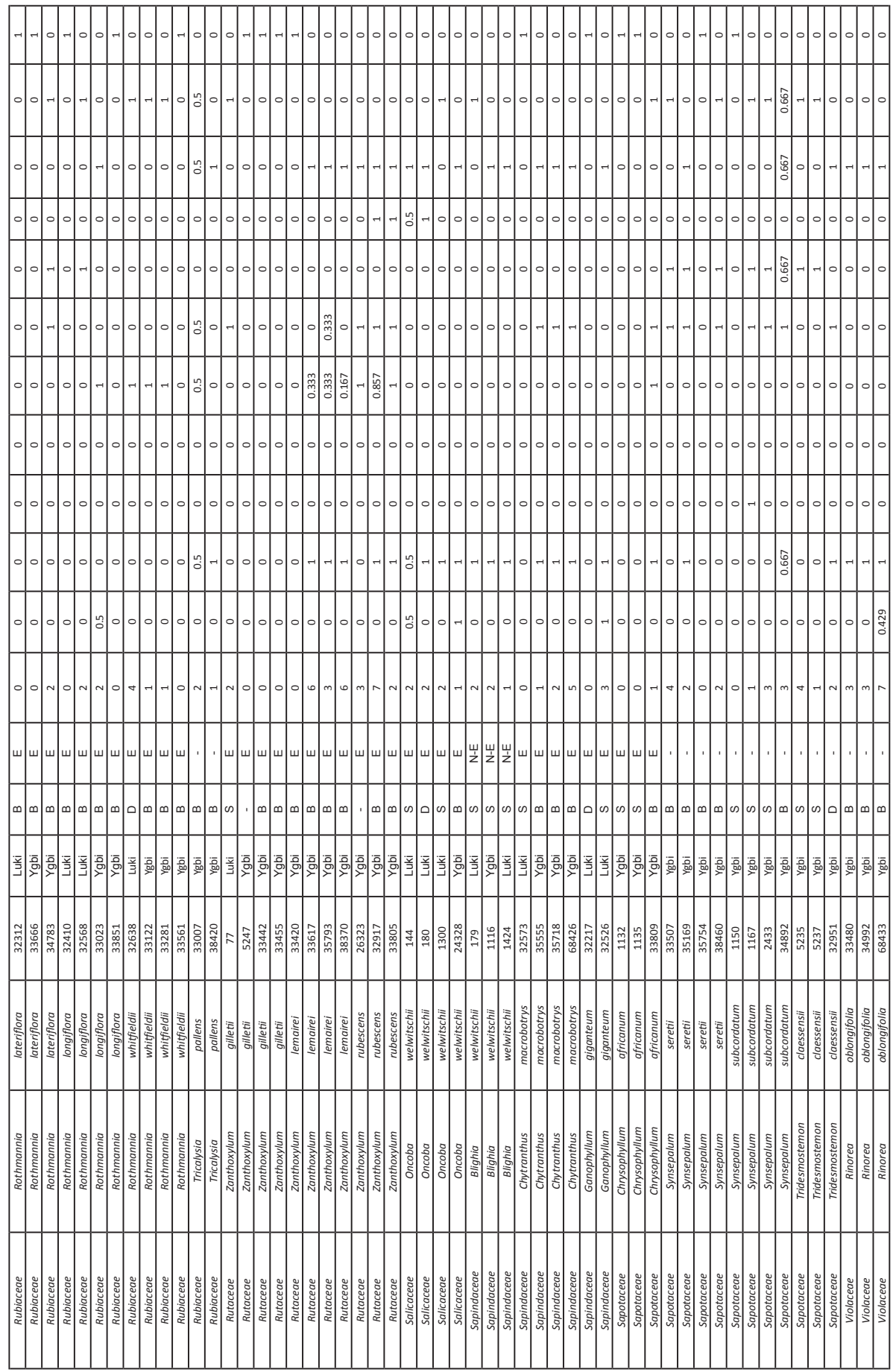

